\title{
Pengaruh Sitokinin Eksogen dan Sukrosa terhadap Produksi Biomassa dan Alkaloid Canthinone di dalam Kultur Suspensi Sel Pasak Bumi (Eurycoma longifolia Jack.)
}

\author{
Luthfi Aziz Mahmud Siregar \\ Program Studi Pemuliaan Tanaman, Fakultas Pertanian, Unversitas Sumatera Utara, Medan 20155 \\ Diterima 23-04-2009 Disetujui 05-11-2009
}

\begin{abstract}
The effect of addition cytokinins and modification of sucrose concentration on growth and alkaloid canthinone production in cell suspension cultures of Eurycoma longifilia Jack were studied. The additions of cytokines, BA and kinetin, show effect on the production of biomass and alkaloid in cell suspension of $E$. longifilia Jack. The optimum totals of two-alkaloids were obtained on addition $4.44 \mu \mathrm{M}$ BAP and without kinetin, respectively. The addition of 4.44 $\mu \mathrm{M}$ BA (6-benzyladenine) into TAM medium stimulated increased total of 9-hydroxycanthine-6-one, but decreased total of 9-methoxycanthin-6-one. While the addition of 2.32 - $9.29 \mu \mathrm{M}$ kinetin (6-furfurylaminopurine) into TAM medium decreased total of two alkaloids (from $0.582 \mathrm{mg}$ to $0.461-0.257 \mathrm{mg}$ per $25 \mathrm{ml}$ medium). When sucrose concentration in TAM medium was increased from $3 \%$ to $5 \%$, production of biomass would increase from $0.374 \mathrm{~g}$ to $0.585 \mathrm{~g}$ dry weight per $25 \mathrm{ml}$ medium. While total of two-alkaloids increase from $0.328 \mathrm{mg}$ to $0.441 \mathrm{mg}$ per $25 \mathrm{ml}$ medium when concentration of sucrose in TAM medium was increased from $3 \%$ to $4 \%$ sucrose.
\end{abstract}

Keywords: canthinone, cell suspension, cytokinin, Eurycoma longifolia Jack, sucrose

\section{PENDAHULUAN}

Eurycoma longifolia Jack (Pasak Bumi), tanaman obat yang termasuk dalam Famili Simaroubaceae dan dijumpai tumbuh secara meluas di Malaysia, Indonesia, Thailand dan Vietnam. Tanaman ini menghasilkan quassinoid, canthin-6-one dan turunannya, turunan squalane, triterpene tipe tirucalane sebagai hasil metabolisme primer dan skunder (Chan et al., 1986; Chan et al., 1989; Darise et al. 1982; Kardono et al., 1991; Itokawa et al., 1991; Itokawa et al., 1992; Morita et al., 1993). Komponen-komponen aktif ini dilaporkan mempunyai aktifitas biologi sebagai anti-malaria, sitotoksik, afrodisiak dan anti-ulser (Ang et al., 1997; Chan et al., 1986, Kardono et al. 1991, Tada et al., 1991). Kardono et al., (1991) melaporkan bahwa tumbuhan Pasak Bumi mengandung alkaloid dari golongan canthinone, yaitu 9-methoxycanthin-6-one dan 9-hydroxycanthin-6-one yang digunakan sebagai penanda pokok dan bersifat sitotoksik terhadap beberapa sel kanker. Di samping itu, alkaloid 9-methoxycanthin-6-one menunjukkan aktifitas sebagai agen antimikroba bakteri Bacillus cereus (Choo et al., 2000) dan memiliki potensi yang lebih baik dalam

Telp: +628197240273

Email: luthfi2004@yahoo.com melawan isolat strain Plasmodium falciparum yang resisten klorokuina dibandingkan dengan klorokuina difosfat (Chan et al., 2004).

Kultur sel dan jaringan tanaman secara luas dikenal sebagai alternatif yang menjanjikan untuk produksi metabolit sekunder yang memiliki nilai farmakologi. Beberapa keberhasilan yang telah diperoleh melalui teknik ini seperti produksi komersial shikonin dari Lithospermum erythrorhizon (Fujita 1988), berberine dari Coptis japonica (Fujita 1988), dan taxoldari Taxus species (Blechert \& Guenard 1990). Bagaimanapun, produksi yang rendah selalu menjadi faktor pembatas yang tidak menguntungkan dalam proses komersialisasi. Metode ini dapat dikembangkan untuk produksi biomassa dan hasil-hasil metabolisme secara besar-besaran, misalnya dengan menggunakan bioreaktor.

Beberapa kajian in vitro mengenai kultur kalus dan suspensi sel E. longifolia Jack telah dilaporkan sebelumnya. Biomassa kalus dapat diinisiasi dari eksplan daun, petiol dan batang yang diperoleh dari kecambah in vitro E. longifolia Jack (Siregar et al., 1998). Kalus dari eksplan daun yang bersifat mudah hancur (friable) di dalam medium yang mengandung auksin merupakan sumber kalus yang terbaik untuk 
memperoleh kultur suspensi sel (Chan et al., 1999). Berdasarkan analisis kimia menunjukkan bahwa biomassa sel hasil kultur in vitro juga mengandung quasinoid dan alkaloid canthinone seperti halnya kandungan kimia Pasak Bumi yang tumbuh secara alami (Ong et al., 1999). Pemilihan lini sel dan modifikasi konsentrasi makronutrien medium MS dalam kultur suspensi sel E. longifolia Jack telah dilakukan untuk meningkatkan produksi biomassa yang tinggi (Siregar et al., 2003). Disamping itu, berdasarkan kecepatan pertumbuhan kalus dan analisis kimia kuantitatif telah diseleksi lini sel yang menghasilkan biomassa dengan kandungan alkaloid yang tinggi (Siregar et al., 2004).

Inisiasi, proliferasi dan sintesis metabolisme sekunder di dalam kultur suspensi sel dipengaruhi oleh beberapa faktor, yaitu genotip atau sumber sel, komposisi medium dan beberapa faktor fisik. Zat pengatur tumbuh dan sukrosa yang ditambahkan dalam medium kultur merupakan faktor kimia yang membedakan komposisi antara satu medium dengan mendium lainnya karena keperluan untuk pertumbuhan optimum dan produksi bahan-bahan metabolisme sekunder dari setiap jaringan atau sel tumbuhan secara in vitro adalah berbeda untuk masing-masing spesies (Bhojwani \& Razdan 1996). Tumbuhan mengatur tingkat keperluan auksin dan sitokinin melalui sintesis dan konjugasi zat pengatur tumbuh tersebut (Endress 1994). Jenis dan konsentrasi auksin dan sitokinin atau zat pengatur tumbuh lainnya yang ditambahkan ke dalam medium kultur juga menjadi faktor penting dalam mempengaruhi sintesis bahan metabolit sekunder. Disamping itu, sukrosa selalu digunakan sebagai sumber karbon dan energi yang diperlukan untuk pertumbuhan dalam kultur suspensi sel. Kultur sel di dalam medium cair yang mengandung sukrosa biasanya dicirikan dengan tingkat pembentukan vakuola yang rendah dalam proses penebalan dinding sel dan penimbunan polisakarida (Endress 1994).

Oleh karena itu, kertas kerja ini akan melaporkan suatu kajian mengenai pengaruh penambahan zat pengatur tumbuh sitokinin dan modifikasi konsentrasi sukrosa terhadap produksi biomassa dan alkaloid canthinone di dalam kultur suspensi sel $E$. longifolia Jack. Kajian ini dilaksanakan sebagai suatu upaya untuk meningkatkan kapasitas dan kemampuan sel untuk menghasilkan metabolit sekunder khususnya senyawa canthinone yang berasal dari E. longifolia Jack.
Penyediaan kultur suspensi sel E. longifolia Jack. Penelitian dilaksanakan di Laboratorium Kultur Sel dan Jaringan Tanaman, Pusat Pengajian Sains Kajihayat, Universiti Sains Malaysia, Penang, Malaysia. Kultur suspensi sel E. longifolia Jack diinisiasi dari kalus daun yang berasal dari lini sel Eu9 (lini sel yang terbaik dalam produksi biomassa) (Siregar et al., 2003; 2004). Sel-sel sebanyak 1,0 g berat basah dan berumur 12 hari dikultur ke dalam gelas Erlenmeyer (100 ml) yang mengandung $25 \mathrm{ml}$ medium cair TAM $+2,69 \mu \mathrm{M}$ asam $\alpha$-naftalenasetat (NAA) and 1,13 $\mu \mathrm{M}$ asam 2,4-diklorofenoksiasetat (2,4-D) (Siregar 2003). Medium TAM merupakan medium MS (Murashige \& Skoog 1962) yang mengalami modifikasi dalam komponen makronutriennya. Komposisi makronutrien medium TAM yaitu 21,50 $\mathrm{mM} \mathrm{NH}_{4} \mathrm{NO}_{3}$, $12,25 \mathrm{mM} \mathrm{KNO}_{3}, 3,10 \mathrm{mM} \mathrm{CaCl}, 2 \mathrm{H}_{2} \mathrm{O}, 0,58 \mathrm{mM}$ $\mathrm{MgSO}_{4}, 7 \mathrm{H}_{2} \mathrm{O}$, and $1,83 \mathrm{mM} \mathrm{KH}_{2} \mathrm{PO}_{4}$. Suspensi sel $E$. longifolia Jack disubkultur ke dalam medium baru yang sama setiap 12 hari. pH medium kultur ditetapkan pada $\mathrm{pH}$ 5,7 sebelum disterilisasi. Sebelum digunakan, medium disterilisasi dalam autoklaf (Tomy ${ }^{\circledR}$ SS-325 Autoclave) pada suhu $121^{\circ} \mathrm{C}$ selama 13 menit. Kultur suspensi sel ditempatkan pada pengguncang berputar (G10 Gyrotory Shaker ${ }^{\circledR}$, New Brunswick Scientific, N.J. U.S.A) dengan kecepatan $130 \mathrm{rpm}$, suhu ruangan 25 $2^{\circ} \mathrm{C}$ dengan intensitas cahaya fluoresen putih $18 \mu \mathrm{Em}$ ${ }^{2} \mathrm{~S}^{-1}$. Biomassa sel dan medium cair dipisahkan dengan menggunakan kertas saring (Whatman $®, ~ \varnothing 110 \mathrm{~mm}$ ) yang diletakkan pada corong pengisap $(\varnothing 90 \mathrm{~mm})$ dan terhubung dengan pompa vakum. Biomassa sel dikeringkan pada suhu ruangan $24 \pm 2^{\circ} \mathrm{C}$ sehingga diperoleh berat yang konstan.

Pengaruh sitokinin dan sukrosa. Satu gram biomassa sel Eu9 yang berasal dari kultur suspensi sel E. longifolia Jack di dalam medium cair TAM + 2,69 $\mu \mathrm{M}$ NAA + 1,13 $\mu \mathrm{M}$ 2,4-D, disubkulturkan ke dalam $100 \mathrm{ml}$ gelas Erlenmeyer yang mengandung 25 $\mathrm{ml}$ medium perlakuan. Untuk mengetahui pengaruh sitokinin terhadap produksi biomassa dan canthinone, medium perlakuan yang digunakan dalam kajian ini yaitu medium cair TAM $+2,69 \mu \mathrm{M} N A A+1,13 \mu \mathrm{M}$ 2,4-D ditambah dengan perlakuan: (a) BA (6benziladenin) dengan konsentrasi 0, 2,22, 4,44, 6,66 dan $8.88 \mu \mathrm{M}$; dan (b) kinetin (6-furfurilaminopurin) dengan konsentrasi 0, 2,32, 4,65, 6,97 dan 9,29 $\mu \mathrm{M}$. Sedangkan untuk mengetahui pengaruh sukrosa, maka medium diberi perlakuan konsentrasi sukrosa yang berbeda yaitu 0, 1, 2, 3 (kontrol), 4, 5, 6 dan 
$7 \%$ (w/v). Biomassa sel hasil dari kultur suspensi sel ini dipanen pada 14 hari setelah kultur.

Analisis data. Penelitian ini menggunakan Rancangan Acak Kelompok (RAK) non faktorial. Tiga kultur (replikat) digunakan untuk setiap perlakuan dengan menggunakan 3 (tiga) ulangan. Data peningkatan berat basah dan berat kering dianalisis dengan ANOVA dua arah, sedangkan grafik pengaruh konsentrasi perlakuan (BA, kinetin dan sukrosa) terhadap parameter peningkatan berat basah, berat kering, konsentrasi 9-methoxycanthin-6-one dan 9hydroxycanthin-6-one, total 9-methoxycanthin-6-one dan 9-hydroxycanthin-6-one, dan total dua-alkaloid ditentukan dengan menggunakan program komputer Microsoft ${ }^{\circledR}$ Excel.

Analisis alkaloid. Metode ekstraksi dan analisis alkaloid biomassa sel E. longifolia Jack ini disesuaikan dari metode yang telah dilakukan oleh Liu et al., (1990) untuk ekstraksi alkaloid dari tumbuhan Brucea javanica (Simaroubaceae). Biomassa (0,50 g) yang dikeringkan secara kering-beku (freeze-dry) direndam dalam heksana untuk menghilangkan lemak. Selanjutnya sampel diekstrak dalam $20 \mathrm{ml}$ metanol selama 24 jam pada suhu ruang $25 \pm 2 \mathrm{C}$ sebanyak tiga kali. Setelah penyaringan dengan kertas filter Whatman® No.1, ekstrak metanol dikeringkan dengan alat evaporator pada suhu $45^{\circ} \mathrm{C}$. Untuk analisis HPLC, residu kering dilarutkan di dalam $5 \mathrm{ml}$ metanol dan disaring dengan millipore $(\varnothing 0,45 \mu \mathrm{m}$, Whatman®). Analisis HPLC dilakukan dengan penyuntikan sampel ke dalam suatu injektor (20 $\mu \mathrm{l}$, Rheodyne, USA) yang disambung kepada suatu kolom fase berbalik dengan ukuran partikel $5 \mu \mathrm{m}$ dan panjang 250 x 4,6 mm (Hypersil ${ }^{\circledR}$ ODS column). Deteksi dilakukan dengan sinar ultra violet dari suatu alat SPD-10 A Vp Shimadzu UV-VIS. HPLC dijalankan dengan pompa tekanan tinggi LC-10 AD Vp Shimadzu Liquid Chromatograph. Semua peralatan dan tatacara analisis dikontrol dengan suatu program komputer Shimadzu Class Vp. Fase gerak mengandungi asetonitril (Fisher Scientific): 0,2\% asam asetat (Merck, Germany) (42:58) dengan kecepatan aliran $2 \mathrm{ml} /$ menit. Kehadiran alkaloid dimonitor pada $280 \mathrm{~nm}$ dan diidentifikasi berdasarkan kepada masa retensi $\left(t_{R}\right)$.

\section{HASIL DAN PEMBAHASAN}

Pengaruh BA. Penambahan 4,44 $\mu \mathrm{M}$ BA ke dalam $25 \mathrm{ml}$ medium cair TAM + 2,69 $\mu \mathrm{M} \mathrm{NAA}+1,13$ $\mu \mathrm{M} 2,4-\mathrm{D}$ menunjukkan rataan yang tertinggi $(6,658 \mathrm{~g})$ pada parameter peningkatan berat basah dan ini berbeda nyata dibandingkan dengan tanpa $(6,162 \mathrm{~g})$ atau penambahan 2,22 $\mu \mathrm{M}(6.106 \mathrm{~g}), 6,66 \mathrm{M}(5.583 \mathrm{~g})$ dan $8,88 \mu \mathrm{M}$ BA $(5,468 \mathrm{~g})$. Sedangkan untuk berat kering, penambahan $4,44 \mu \mathrm{MBA}(0,346 \mathrm{~g})$ menunjukkan perbedaan yang nyata dengan penambahan 6,66 M BA $(0,313 \mathrm{~g})$ dan 8,88 $\mu \mathrm{M} \mathrm{BA}(0,308 \mathrm{~g})$, tetapi tidak berbeda nyata dengan tanpa $(0,339 \mathrm{~g})$ atau penambahan 2,22 $\mu \mathrm{M}$ BA $(0,342 \mathrm{~g})$ (Gambar 1A). Sehubungan dengan peranan BA terhadap produksi biomassa sel $E$. longifolia Jack, suatu fenomena yang berbeda dihasilkan dalam kultur kalus Taxus brevifolia, bahwa kombinasi 4,52 $\mu \mathrm{M}$ 2,4-D + 0,44 $\mu \mathrm{M}$ BAP di dalam medium Gamborg B5 tidak mempengaruhi peningkatan pertumbuhan tiga lini sel kalus Taxus brevifolia, tetapi medium yang ditambahkan dengan kombinasi 4,52 $\mu \mathrm{M}$ 2,4-D + 0,47 $\mu \mathrm{M}$ kinetin atau 4,52 $\mu \mathrm{M} 2,4-\mathrm{D}+0,49 \mu \mathrm{M}$ 2iP mendukung pertumbuhan kalus yang terbaik jika dibandingkan hanya dengan penambahan 2,4-D saja (Ketchum et al., 1995).

Penambahan BA ke dalam medium TAM + 2,69 $\mu \mathrm{M} N A A+1,13 \mu \mathrm{M}$ 2,4-D mempengaruhi kandungan 9-hydroxycanthin-6-one dan 9-methoxycanthin-6-one dalam biomassa sel. Biomassa sel yang dikultur di dalam medium tanpa BA menghasilkan $0.086 \%$ 9-hydroxycanthin-6-one. Berdasarkan nilai rataan, persentase alkaloid 9-hydroxycanthin-6-one yang optimum dapat diperoleh dalam medium kultur yang ditambahkan 4,44 $\mu \mathrm{M}$ BA. Konsentrasi 9-hydroxycanthin-6-one menjadi rendah apabila konsentrasi BA ditingkatkan lebih dari 6,66 $\mu \mathrm{M}$. Sedangkan, penambahan 2,22-8,88 $\mu \mathrm{M}$ BA ke dalam medium menghasilkan kandungan 9-methoxycanthin6 -one yang lebih rendah dibandingkan tanpa penambahan $B A(0,062 \% \pm 0.003)$. Dalam kajian ini, penambahan 4,44 $\mu \mathrm{M}$ BA menghasilkan kadar 9-methoxycanthin-6-one yang paling rendah, yaitu hanya $0.024 \% \pm 0.005$ dihasilkan (Gambar $1 \mathrm{~B}$ ).

Diperlukan konsentrasi BA optimum yang berbeda untuk menghasilkan kandungan total 9-hydroxycanthin6-one dan 9-methoxycanthin-6-one yang tinggi di dalam biomassa sel $E$. longifolia Jack. Kandungan total 9-methoxycanthin-6-one tertinggi diperoleh tanpa pemberian zat pengatur tumbuh BA (0,211 mg per $25 \mathrm{ml}$ medium), sedangkan kandungan total 9-hydroxycanthin-6-one tertinggi diperoleh pada konsentrasi 4,44 $\mu \mathrm{M}$ BA $(0,487 \mathrm{mg}$ per $25 \mathrm{ml}$ medium). Di samping menghasilkan biomassa sel yang tinggi, penambahan 4.44 $\mu \mathrm{M}$ BA di dalam $25 \mathrm{ml}$ medium TAM 

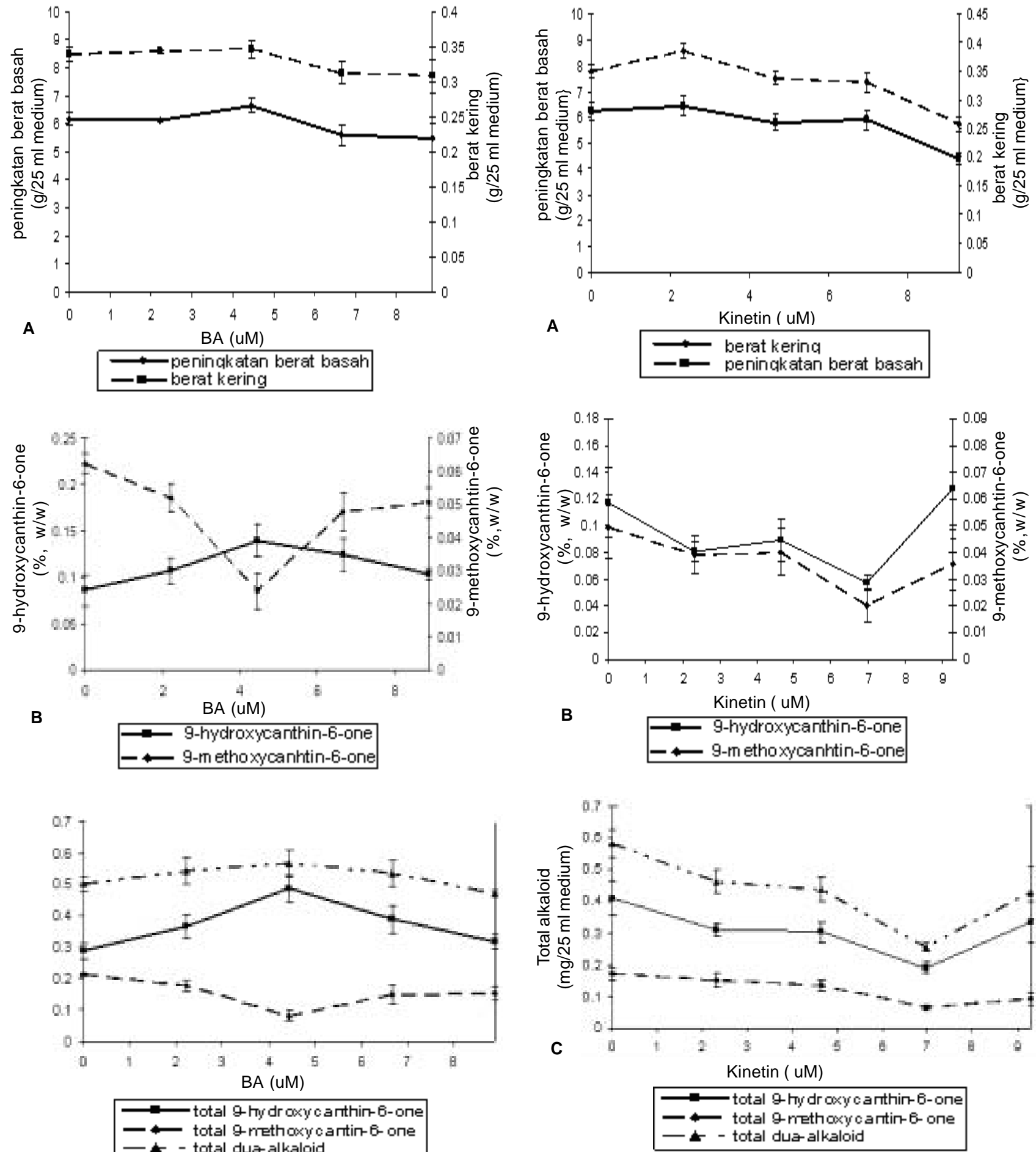

Gambar 1. Pengaruh konsentrasi BA $(0-8.88 \mu \mathrm{M})$ dalam $25 \mathrm{ml}$ medium cair TAM + $2.69 \mu \mathrm{M} N A A+1.13 \mu \mathrm{M}$ 2,4-D terhadap produksi biomassa sel $(\mathrm{A})$, konsentrasi 9hydroxycanthin-6-one dan 9-methoxycanthin-6-one (B), dan total 9-hydroxycanthin-6-one, total 9methoxycanthin-6-one dan total dua-alkaloid (C) di dalam kultur suspensi sel E. longifolia Jack pada 14 hari setelah kultur.

$+2,69 \mu \mathrm{M} N A A+1,13 \mu \mathrm{M}$ 2,4-D juga menghasilkan kandungan total dua-alkaloid yang paling tinggi, yaitu $0,584 \mathrm{mg}$ per $25 \mathrm{ml}$ dalam 14 hari setelah kultur (Gambar 1C).

Produksi alkaloid memperlihatkan fenomena yang berbeda antara kultur suspensi sel $E$. longifolia Jack

Gambar 2. Pengaruh konsentrasi Kinetin $(0-9.29 \mathrm{M})$ dalam $25 \mathrm{ml}$ medium cair TAM + $2.69 \mu \mathrm{M} N A A+1.13 \mu \mathrm{M} 2,4-\mathrm{D}$ terhadap produksi biomassa sel (A), konsentrasi 9hydroxycanthin-6-one dan 9-methoxycanthin-6-one (B), dan total 9-hydroxycanthin-6-one, total 9methoxycanthin-6-one dan total dua-alkaloid (C) di dalam kultur suspensi sel E. longifolia Jack pada 14 hari setelah kultur.

di atas dengan kultur suspensi sel Brucea javanica, spesies yang termasuk dalam satu famili dengan tanaman Pasak Bumi. Dalam kultur suspensi E. longifolia Jack, penambahan BA hanya meningkatkan kandungan 9-hydroxycanthin-6-one, 

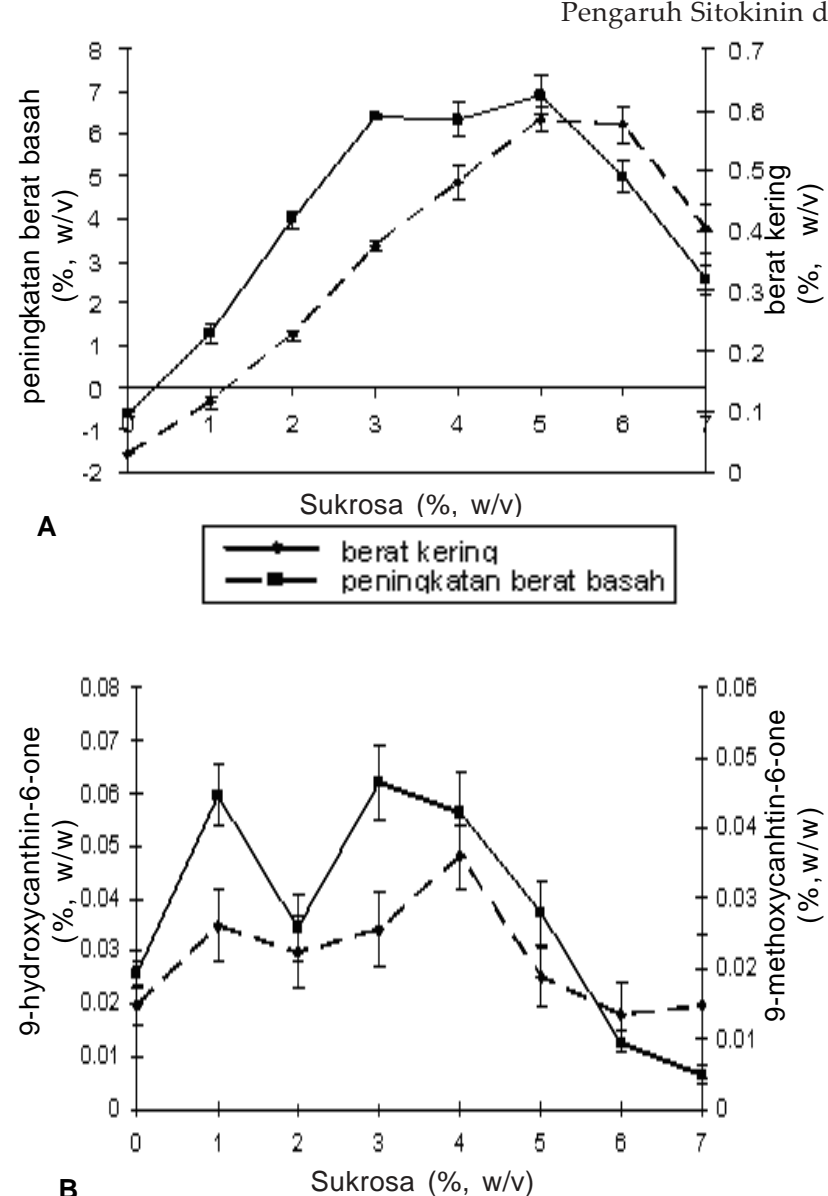

B - 9-hydroxycanthin-6-one
$-\leftarrow$ 9-m ethoxycanhtin-6-one

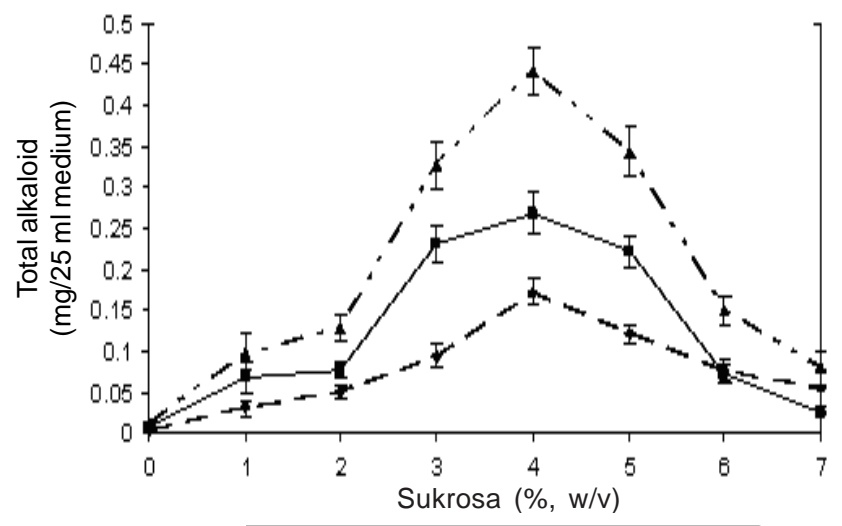

Gambar 3. Pengaruh konsentrasi sukrosa $(0-7 \%$, w/v) dalam $25 \mathrm{ml}$ medium cair TAM $+2.69 \mu \mathrm{M} N A A+1.13 \mu \mathrm{M}$ 2,4-D terhadap produksi biomassa sel (A), konsentrasi 9-hydroxycanthin-6-one dan 9methoxycanthin-6-one (B), dan total 9hydroxycanthin-6-one, total 9-methoxycanthin-6-one dan total dua-alkaloid (C) di dalam kultur suspensi sel E. Iongifolia Jack pada 14 hari setelah kultur.

tetapi mengakibatkan turunnya konsentrasi 9-methoxycanthin-6-one di dalam sel. Sedangkan dalam kultur suspensi sel Brucea javania, produksi yang lebih efektif untuk produksi canthin-6-one, 11-hydroxycanthinmedium TAM + 2,69 $\mu \mathrm{M} N A A+1,13 \mu \mathrm{M}$ 2,4-D tanpa

Sukrosa di dalam Kultur Suspensi Sel Pasak Bumi

147 6-one, 11-methoxycanthin-6-one dan 5-methoxycanthin6-one diperoleh dalam suatu medium MS cair yang mengandung $20 \mathrm{mg} / \mathrm{l}$ sukrosa dan $1 \mathrm{mg} / \mathrm{l}(4,44 \mu \mathrm{mM})$ BA (Liu et al., 1994). Pada tanaman obat lainnya, pertumbuhan dan produksi jaceosidin di dalam kultur suspensi sel Saussurea medusa diperoleh dalam medium MS cair yang mengandung kombinasi $2 \mathrm{mg} / \mathrm{l}$ $(10,74 \mu \mathrm{M}) \mathrm{NAA}+0,2 \mathrm{mg} / \mathrm{l}(0,89 \mu \mathrm{M}) \mathrm{BA}$ (Zhao et al., 2001).

Pengaruh Kinetin. Konsentrasi kinetin $(0-9,29$ $\mu \mathrm{M})$ di dalam medium cair TAM $+2,69 \mu \mathrm{M} N A A+1,13$ $\mu \mathrm{M}$ 2,4-D mempengaruhi produksi biomassa sel dan konsentrasi alkaloid dalam kultur suspensi sel $E$. longifolia Jack 14 hari setelah kultur. Peningkatan konsentrasi kinetin dalam medium lebih dari 2,32 $\mu \mathrm{M}$ menyebabkan produksi biomassa sel semakin rendah. Konsentrasi kinetin yang optimum untuk menghasilkan pertumbuhan biomassa tertinggi ( $6,428 \mathrm{~g}$ peningkatan berat basah atau $0,385 \mathrm{~g}$ berat kering) dihasilkan dalam medium yang mengandung 2,32 $\mu \mathrm{M}$ kinetin (Gambar 2A). Grzelak \& Janiszowska (2002) melaporkan bahwa dua kombinasi zat pengatur tumbuh di dalam medium MS digunakan untuk mendorong produksi biomassa kalus dan kultur suspensi sel Calendula officinalis, yaitu MS + 1,81 $\mu \mathrm{M} 2,4-\mathrm{D}+1,85 \mu \mathrm{M}$ kinetin dan MS + $0,45 \mu \mathrm{M} 2,4-\mathrm{D}+2,02 \mu \mathrm{M} 2 \mathrm{iP}$.

Penambahan kinetin pada konsentrasi 2,32 $\mu \mathrm{M}$ $6,97 \mu \mathrm{M}$ ke dalam medium TAM $+2,69 \mu \mathrm{M} N A A+1,13$ $\mu \mathrm{M}$ 2,4-D menyebabkan penurunan konsentrasi 9hydroxycanthin-6-one dan 9-methoxycanthin-6-one. Produksi 9-hydroxycanthin-6-one dan 9-methoxycanthin6-one akan meningkat kembali jika konsentrasi kinetin ditingkatkan menjadi 9,29 $\mu \mathrm{M}$. Hasil kajian menunjukkan bahwa konsentrasi 9-hydroxycanthin-6one dan 9-methoxycanthin-6-one yang optimum dapat diperoleh masing-masing dalam medium kultur tanpa penambahan zat pengatur tumbuh kinetin (Gambar 2B).

Dalam medium TAM $+2,69 \mu \mathrm{M} N A A+1,13 \mu \mathrm{M}$ 2,4-D tanpa mengandung kinetin, kandungan total 9hydroxycanthin-6-one dalam sel-sel $E$. longifolia Jack dapat diperoleh sebanyak 0,411 mg per $25 \mathrm{ml}$ medium. Kandungan total 9-hydroxycnthin-6-one menunjukkan penurunan pada konsentrasi $2,32 \mu \mathrm{M}-6,97 \mu \mathrm{M}$ kinetin (0,310 - 0,191 $\mathrm{mg}$ per $25 \mathrm{ml}$ medium) dan kembali meningkat hingga $0,334 \mathrm{mg}$ pada konsentrasi $9,29 \mu \mathrm{M}$ kinetin. Sedangkan kandungan total 9-methoxycanthin6-one semakin menurun $(0,151-0,093 \mathrm{mg}$ per $25 \mathrm{ml}$ medium) dengan penambahan kinetin $(2,32-9,29 \mu \mathrm{M})$. Kandungan total 9-methoxycanthin-6-one optimum dapat diperoleh $(0,171 \mathrm{mg}$ per $25 \mathrm{ml}$ medium) dalam 
kinetin. Untuk kandungan total dua-alkaloid, medium cair TAM + 2,69 $\mathrm{MM} \mathrm{NAA}+1,13 \mu \mathrm{M} 2,4-\mathrm{D}$ yang ditambahkan 2,32 $\mu \mathrm{M}-9,29 \mu \mathrm{M}$ kinetin menunjukkan penurunan kandungan total dua-alkaloid $(0,461-0,257$ mg per $25 \mathrm{ml}$ medium) dibandingkan dengan medium tanpa kinetin yang menunjukkan produksi alkaloid tertinggi, yaitu $0,582 \mathrm{mg}$ per $25 \mathrm{ml}$ medium (Gambar 2C).

Kajian kultur suspensi sel E. longifolia Jack di atas menunjukkan bahwa penambahan kinetin mengakibatkan penurunan kandungan total alkaloid yang dihasilkan didalam sel. Suatu fenomena yang berbeda dari kultur suspensi sel E. longifolia Jack dengan kultur suspensi sel Brucea javanica, bahwa penambahan $0.1 \mathrm{mg} / \mathrm{l}(0,47 \mu \mathrm{M})$ kinetin ke dalam medium $\mathrm{MS}+$ $2 \mathrm{mg} / \mathrm{l}(10,74 \mu \mathrm{M})$ NAA dapat meningkatkan produksi empat alkaloid (11-hydroxycanthin-6-one, 11 methoxycanthin-6-one canthin-6-one and 5-methoxycanthin-6-one), bahkan empat alkaloid tersebut lebih banyak ditemukan dalam medium kultur sebagai hasil ekskresi dibandingkan dalam biomassa sel (Liu et al., 1994).

Kehadiran sitokinin-kinetin di dalam kultur suspensi sel $E$. longifolia Jack menunjukkan keadaan yang tidak mendukung peningkatan kandungan total alkaloid yang dihasilkan. Minghetti et al., (1996) melaporkan bahwa di dalam kultur suspensi sel Euphorbia calyptrata, peningkatan total HELs (helioscopinolides) di dalam biomassa sel diperoleh dalam medium cair Gamborg B5 tanpa zat pengatur tumbuh, tetapi mereka juga menemukan bahwa produksi helioscopinolide jenis HELs F dan HELs H dihasilkan lebih tinggi di dalam medium Gamborg B5 yang mengandung 0,27 $\mu \mathrm{M}$ NAA $+4,65 \mu \mathrm{M}$ kinetin dan $5,37 \mu \mathrm{MNAA}+4.65 \mu \mathrm{M}$ kinetin. Di samping itu, Hayashi et al., (1988) juga melaporkan bahwa konsentrasi kinetin yang tinggi dalam medium dapat menghambat produksi colchisin dalam kultur suspensi sel Colchicum autumnale, sedangkan penambahan IBA dapat merangsang pertumbuhan sel di dalam medium yang mengandung kinetin.

Pengaruh Sukrosa. Konsentrasi sukrosa yang berbeda di dalam $25 \mathrm{ml}$ medium cair TAM $+2.69 \mu \mathrm{M}$ $\mathrm{NAA}+1,13 \mu \mathrm{M}$ 2,4-D menunjukkan pengaruh yang nyata terhadap produksi biomassa sel, konsentrasi 9 hydroxycanthin-6-one dan 9-methoxycanthin-6-one, dan kandungan total dua-alkaloid di dalam sel-sel $E$. longifolia Jack setelah 14 hari kultur.

Penambahan sukrosa sebanyak $3 \%$ sama dengan konsentrasi sukrosa dalam MS dasar) ke dalam medium
TAM + 2,69 $\mu \mathrm{M}$ NAA + 1,13 $\mu \mathrm{M}$ 2,4-D menghasilkan $6,417 \mathrm{~g}$ peningkatan berat basah dan $0,374 \mathrm{~g}$ berat kering sel-sel $E$. longifolia Jack dalam setiap $25 \mathrm{ml}$ medium. Produksi berat basah dan berat kering semakin rendah jika konsentrasi sukrosa kurang dari $3 \%$. Medium tanpa sukrosa mengakibatkan penurunan berat basah biomassa sel menjadi kurang dari $1 \mathrm{~g}$, sehingga berat basah sel kurang daripada berat inokulum. Penambahan sukrosa ke dalam medium lebih dari $5 \%$ juga mengakibatkan penurunan berat basah, sedangkan penambahan sukrosa lebih dari 6\% menurunkan produksi berat kering biomassa sel. Konsentrasi sukrosa yang optimum untuk menghasilkan peningkatan berat basah dan berat kering biomassa sel yang paling tinggi adalah 5\% (6,935 g peningkatan berat basah dan 0,585 $\mathrm{g}$ berat kering per $25 \mathrm{ml}$ medium) (Gambar 3A).

Jika konsentrasi sukrosa dalam medium ditetapkan pada $2 \%$, hal ini mengakibatkan hanya 0,035\% 9-hydroxycanthin-6-one dan 0,022\% 9-methoxycanthin-6-one yang diproduksi oleh sel-sel E. longifolia Jack, lebih rendah dibandingkan dengan medium yang mengandung sukrosa $3 \%$ yang menghasilkan sebanyak 0,062\% 9-hydroxycanthin-6one dan 0,026\% 9-methoxycanthin-6-one. Konsentrasi alkaloid 9-hydroxycanthin-6-one yang paling tinggi diperoleh dalam medium cair TAM + 2,69 $\mu \mathrm{M}$ NAA + $1,13 \mu \mathrm{M} 2,4-\mathrm{D}$ yang mengandung $3 \%$ sukrosa $(0,062 \%)$, sedangkan konsentrasi 9-methoxycanthin6 -one yang paling tinggi diperoleh dalam medium dengan penambahan sukrosa $4 \%(0,036 \%)$. Peningkatan keonsentrasi sukrosa lebih dari $4 \%$ menyebabkan konsentrasi 9-methoxycanthin-6-one dan 9-hydroxycanthin-6-one menjadi semakin rendah (Gambar 3B).

Pengaruh penambahan sukrosa terhadap kandungan total alkaloid (9-hydroxycanthin-6-one, 9-methoxycanthin-6-one dan total dua-alkaloid) di dalam biomassa sel yang dihasilkan dari kultur suspensi sel E. longifolia Jack di dalam medium TAM $+2,69 \mu \mathrm{M}$ $\mathrm{NAA}+1,13 \mu \mathrm{M} 2,4-\mathrm{D}$ menunjukkan peningkatan jika konsentrasi sukrosa ditingkatkan hingga 4\% (0,441 mg per $25 \mathrm{ml}$ medium). Penambahan $0-3 \%$ sukrosa hanya menghasilkan 0,013 - 0,328 mg total dua-alkaloid per $25 \mathrm{ml}$ medium. Di samping itu, kandungan total duaalkaloid juga akan menurun apabila konsentrasi sukrosa ditingkatkan menjadi 5-7\% (0,344-0,081 mg per $25 \mathrm{ml}$ medium) (Gambar 3C).

Sumber karbon merupakan komponen utama yang perlu ditambahkan ke dalam medium kultur untuk 
pertumbuhan sel atau proses produksi bahan metabolit sekunder. Untuk kultur suspensi sel E. longifolia Jack, penambahan sukrosa hingga $5 \%$ dapat meningkatkan produksi biomassa sel, tetapi peningkatan biomassa sel tidak diikuti dengan peningkatan produksi alkaloid di dalamnya. Produksi 9-methoxycanthin-6-one dan 9hydroxycanthin-6-one yang optimum diperoleh dalam medium TAM yang mengandung masing-masing $3 \%$ dan $4 \%$ sukrosa. Penambahan lebih dari 5\% menurunkan produksi alkaloid. Konsentrasi sukrosa yang optimum untuk menghasilkan kandungan total dua-alkaloid yang paling tinggi ialah 4\%. Fenomena yang sama ditemukan juga dalam kultur akar Salvia fruticosa dengan menghasilkan rosmarinic acid yang optimum di dalam medium B5 yang mengandungi 4\% sukrosa (Karam et al., 2003). Morimoto et al., (1988) melaporkan bahwa konsentrasi optimum untuk pertumbuhan biomassa sel dan produksi berberine di dalam kultur suspensi sel Coptis japonica dihasilkan dalam medium yang ditambahkan dengan $4 \%$ dan $2 \%$ sukrosa. Peningkatan konsentrasi sukrosa lebih dari $3 \%$ menghasilkan berberine yang tetap. Di dalam kultur suspensi sel Anchusa officinalis, pertumbuhan dan kandungan rosmarinic acid diperoleh paling tinggi di dalam medium B5 + 4,52 $\mu \mathrm{M} 2,4-\mathrm{D}+0,47 \mu \mathrm{M}$ kinetin dengan $3 \%$ sukrosa, sedangkan pada konsentrasi sukrosa lebih atau kurang dari 3\% mengakibatkan pertumbuhan dan produksi rosmarinic acid yang semakin rendah (De-Eknamkul dan Ellis 1985). Biosintesis saponin dapat ditingkatkan di dalam medium cair MS dengan meningkatkan konsentrasi sukrosa antara 6-8\% di dalam kultur suspensi sel Panax ginseng (Akalezi et al., 1999). Dengan meningkatkan konsentrasi $3 \%$ sukrosa menjadi $6 \%$ sukrosa di dalam medium cair M3 dalam kultur suspensi sel Catharanthus roseus dihasilkan biomassa sel yang tertinggi dan kandungan serpentina dalam sel meningkat empat kali lipat (Scragg et al., 1990).

Alkaloid canthin-6-one (canthinone) dalam kultur kalus dan suspensi sel dari tumbuhan famili Simaroubaceae sudah banyak dideteksi melalui metode kromatografi cair kinerja tinggi (HPLC) maupun kromatografi kolom (Anderson et al., 1983; Liu et al., 1990; Liu et al., 1994; Kanchanapoom et al., 2002). Crespi-Perellino et al,. (1986) telah menjelaskan suatu lintasan biosintesis alkaloid canthinone yang dihasilkan dari kultur suspensi sel Ailanthus altissima dengan bantuan prekursor tryptophan. Lintasan biosintesis alkaloid tersebut ialah: tryptophan '! â-carboline-1propionic acid'! 4,5-dihydrocanthin-6-one '! canthin-6- one '! 1-hydroxycanthin-6-one '! 1-metoxycanthin-6-one '! 1-metoxycanthin-6-one-3-oxyde. Berdasarkan lintasan biosintesis tersebut, alkaloid 9-hydroxycanthin-6-one dan 9-metoxycanthin-6-one yang terdapat dalam biomassa kultur suspensi sel $E$. longifolia Jack kemungkinan memiliki lintasan yang sama dengan alkaloid canthinone yang terdapat dalam biomassa kultur suspensi sel Ailanthus altissima. Oleh karena itu, penggunaan beberapa jenis prekursor asam amino menjadi suatu yang penting pada kajian berikutnya dalam upaya untuk meningkatkan kandungan alkaloid canthinone dalam biomassa sel E. longifolia Jack.

\section{KESIMPULAN}

Penambahan 4,44 $\mu \mathrm{M}$ BA ke dalam $25 \mathrm{ml}$ medium $\mathrm{TAM}+2,69 \mu \mathrm{M} \mathrm{NAA}+1,13 \mu \mathrm{M}$ 2,4-D dapat meningkatkan produksi biomassa sel $E$. longifolia Jack dari $6,161 \mathrm{~g}$ peningkatan berat basah $(0,339 \mathrm{~g}$ berat kering) menjadi 6,658 $\mathrm{g}$ peningkatan berat basah (0,346 g berat kering). Sedangkan penambahan 4,44 $\mu \mathrm{M}$ BA ke dalam medium kultur dapat meningkatkan kandungan total 9-hydroxycanthin-6-one (dari 0,290 mg menjadi 0,487 mg), tetapi menurunkan kandungan total 9-methoxycanthin-6-one (dari 0,211 mg menjadi 0,082 mg).

Penambahan 2,32 $\mu \mathrm{M}$ kinetin ke dalam $25 \mathrm{ml}$ medium TAM + 2,69 $\mu \mathrm{M}$ NAA + 1,13 $\mu \mathrm{M}$ 2,4-D dapat meningkatkan produksi biomassa sel dari 6,255 g peningkatan berat basah $(0,350 \mathrm{~g}$ berat kering) menjadi $6,428 \mathrm{~g}$ peningkatan berat basah $(0,385 \mathrm{~g}$ berat kering). Namun penambahan 2,32 $\mu \mathrm{M}$ kinetin ke dalam medium kultur dapat menurunkan kandungan total 9-hydroxycanthin-6-one (dari 0,411 mg menjadi 0,310 $\mathrm{mg}$ ) dan 9-methoxycanthin-6-one (dari 0,171 mg menjadi 0,151 mg).

Peningkatan konsentrasi sukrosa dari 3\% (kontrol) menjadi $5 \%$ dapat meningkatkan produksi biomassa sel dari $6,362 \mathrm{~g}$ peningkatan berat basah $(0,379 \mathrm{~g}$ berat kering) menjadi $6,935 \mathrm{~g}$ peningkatan berat basah $(0,585$ $\mathrm{g}$ berat kering). Kandungan total 9-hydroxycanthin-6one dan 9-methoxycanthin-6-one yang tinggi $(0,441 \mathrm{mg}$ per $25 \mathrm{ml}$ medium) dihasilkan di dalam medium yang mengandung $4 \%$ sukrosa.

\section{UCAPAN TERIMA KASIH}

Penulis mengucapkan terima kasih kepada Dr. Tripetch Kanchanaphoom dari Khon Kaen University, Thailand, atas kesediaannya memberikan standard alkaloid yang asli, Sobri bin Aziz untuk bantuan dalam 
analisis HPLC dan Yee Chin Leng untuk bantuannya dalam analisis Spektrometri Massa dari Pusat Pengajian Sains Kimia, Universiti Sains Malaysia.

\section{DAFTAR PUSTAKA}

Anderson, L.A., Harris, A. \& Phillipson, J.D. 1983. Production of cytotoxic canthin-6-one alkaloids by Ailanthus altissima plant cell cultures. J. Nat. Prod. 46: 374-378.

Ang, H.H., Chan, K.L., Gan, E.K. \& Yuen, K.H. 1997. Enhancement of sexual motivation in sexually natïve male mice by Eurycoma longifolia Jack. Int. Journ. Pharmacog. 35(2):144146.

Akalezi, C.O., Liu, S., Li, Q.S., Yu, J.T. \& Zhong, J.J. 1999. Combined effects of initial sucrose concentration and inoculum size on cell growth and ginseng saponin production by suspension cultures of Panax ginseng. Process Biochem. 34: 639-642.

Blechert, S., Guenard, D. 1990. Taxus alkaloids. Di dalam: Brossi, A. (ed.). The Alkaloids. Chapter 6. Vol. 39. San Diego: Academic Press.

Bhojwani, S.S. \& Razdan, M.K. 1996. Plant Tissue Culture: Theory and Practice, A Revised Edition. Netherlands: Elsevier. Amsterdam.

Chan, K.L., O'Neill, M.J., Phillipson, J.D. \& Warhurst, D.C. 1986. Plants as sources of antimalarial drugs. Part 3: Eurycoma longifolia Jack. Planta Med. 52(20): 105-107.

Chan, K.L., Lee, S.P., Sam, T.W. \& Han, B.H. 1989. A quassinoids glycoside from rhe roots of Eurycoma longifolia Jack. Phytochemistry 28(10): 2857-2859.

Chan, L.K., Siregar, L.A.M. \& Chris, Teo, K.H. 1999. In vitro callus and cell cultures of Eurycoma longifolia Jack as affected by types of explants. Proceedings: Seminar of Medicinal Plants-Quality Herbal Products for Healthy Living. Forest Research Institute of Malaysia. CFFPR series: 101 107.

Chan, K.L., Choo, C.Y., Abdullah, N.R. \& Ismail, Z. 2004 Antiplasmodial studies of Eurycoma longifolia Jack using the lactate dehydrogenase assay of Plasmodium falciparum. J. Ethnopharm. 92 (2-3): 223-227.

Choo, C.Y., Nah, B.K., Ibrahim, P. \& Chan, K.L. 2000. Antimicrobial activity of Eurycoma longifolia Jack. Di dalam Rahmani, M., Mahmood, M., Sukari, M.A., Lian, G.E.C., Hin, T.Y.Y. and Ali, D.A.I. (eds.). Interdisciplinary Approaches in Natural Products Research. Proceedings of the 16th National Seminar on Natural Products Department of Chemistry. Universiti Putra Malaysia. Serdang, Malaysia. 219-221.

Crespi-Perellino, N., Guicciardi, A., Malyszko, G.\& Minghetti, A. 1986. Biosynthetic relationship between indole alkoloids produced by cell cultures of Ailanthus altissima. J. Nat. Prod. 49: 814-822.

Darise, M., Kohda, H., Mizutani, K. \& Tanaka, O. 1982. Eurycomanone and Eurycomanol, Quassinoids from The Roots of Eurycoma longifolia. Phytochemistry 21 (8): 2091 2093.

De-Eknamkul, W. \& Ellis, B.E. 1985. Effects of macronutrients on growth and rosmarinic acid formation in cell suspension cultures of Anchusa officinalis. Plant Cell Rep. $4: 46$ - 49.

Endress, R. 1994. Plant Cell Biotechnology. Berlin, Heidelberg: Springer-Verlag. pp. 121-242.

Fujita, Y. 1988. Industrial production of shikonin and berberine. Di dalam Bock, G. and Marsh, J. (eds.), Application of Plant Cell and Tissue Culture. CIBA Foundation Symposium, vol. 137. Chichester: Wiley. pp. 228-235.

Grzelak, A. \& Janiszowska, W. 2002. Initiation and growth characteristics of suspension cultures of Calendula officinalis cells. Plant Cell, Tissue Org. Cult. 71: 29- 40.

Hayashi, T., Yoshida, K. \& Sano, K. 1988. Formation of alkaloidsn suspension-cultured Colchicum autumnale. Phytochemistry 27(5): 1371-1374.

Itokawa, H., Kishi, E., Morita, H., Takeya, K., \& litaka, Y. 1991. Eurylene, a new squelene-type triterpene from Eurycoma Iongifolia. Tetrahedron Letters. 32: 1803-1804.

Itokawa, H., Kishi, E., Morita, H. \& Takeya, K. 1992. Cytotoxic quassinoids and tirucallane-type triterpenes from tne woods of Eurycoma longifolia. Chem. Pharm. Bull. 40: 1053-1055.

Kanchanapoom, T., Chumsri, P., Sonchai, S., Kasai, R. \& Yamasaki, K. 2002. Canthin-6-one alkaloids from callus cultures of Eurycoma longifolia. Nat Medic. 56(2): 55-58.

Karam, N.S. Jawad, F.M., Arikat, N.A. \& Shibli, R.A. 2003. Growth and rosmarinic acid accumulation in callus, cell suspension and root cultures of wild Salvia fruticosa. Plant Cell Tissue Org. Cult. 73: 117-121.

Kardono, L.B.S., Angehofer C.K., Tsauri S., Padmawinata K., Pezzuto J.M. \& Kinghorn D. 1991. Cytotoxic and antimalarial constituents of the roots of Eurycoma longifolia. Journ. Nat. Prod. 54: 1360-1367.

Ketchum, R.E.B., Gibson, D.M. \& Greespan Galo, L. 1995. Media optimization for maximum biomass production in cell cultures of pacific yew. Plant Cell Tissue Org. Cult. 42: 185-193.

Liu, K.C.S., Yang, S.L., Roberts, M.F. \& Phillipson, J.D. 1990. Canthin-6-one alkaloids from cell suspension cultures of Bruceae javanica. Phytochemistry 29(1): 141-143.

Liu, K.C.S., Roberts, M.F., Homeyer, B.C., Yang, S.L. \& Phillipson, J.D. 1994. The effect of plant growth regulators on the production of canthin-6-one alkaloids by Brucea javanica cell suspension cultures. Phytochemistry, 37 (2): 421-424

Minghetti, A., Perellino, N.C., Garofano, L., Speroni, E. \& Vincieri, F.F. 1996. Production of diterpenoids by Euphorbia calyptrata cell cultures. Phytochemistry 42 (6): 1587-1589.

Morita, H., Kishi, E., Takeya, K., Itokawa, H. \& Tanaka, O. 1993. Highly oxygenated qussinoids from Eurycoma longifolia. Phytochemistry 33(3): 691-696.

Morimoto, T., Hara, Y., Kato, Y., Hiratsuka, J., Yoshioka, T., Fujita, Y. \& Yamda, Y. 1988. Berberine production by cultured Coptis japonica cells in a one-stage culture using medium with a high Copper concentration. Agric. Biol. Chem. 52 (7): 1835-1836.

Murashige, T. \& Skoog, F. 1962. A revised medium for rapid growth and bioassays with tobacco tissue cultures. Physiol. Plant. 15: 473-497.

Narayanaswamy, S. 1994. Plant Cell and Tissue Culture. New Delhi: Tata McGraw-Hill Publishing Company Limited.

Ong, B.T. 1999. Perbandingan kualitatif kandungan kimia dalam hasil In vitro Eurycoma longifolia dengan kandungan kimia dalam pokok induk Eurycoma longifolia. Tesis B Sc. Penang: Universiti Sains Malaysia.

Scragg, A.H., Ashton, S., York, A., Bond, P., StepanSarkissian, G. \& Grey, D. 1990. Growth of Catharanthus roseus suspensions for maximum biomass and alkaloid accumulation. Enzyme. Microb. Technol. 12: 292-298.

Siregar, L.A.M., Chan L.K. \& Teo, C.K.H. 1998. In vitro callus and root production of Eurycoma longifolia. Dalam: Towards the sustainable use the bioresoueces - Challenges and opportunities for then IMT-GT. Proceedings of the Second IMT-GT UNINET Conference. Penang, 29-30 August, 1998. 121-123.

Siregar, L.A.M., Chan, L.K., Boey, P.L. 2003. Selection of cell source and the effect of $\mathrm{pH}$ and $\mathrm{MS}$ macronutrients on biomass production in cell cultures of Tongkat Ali (Eurycoma longifolia Jack). J. Plant Biotech. 5(2): 131-135.

Siregar LAM, Chan LK, \& Boey PL (2004) Effect of cell source and $\mathrm{pH}$ culture medium on the production of canthin-6-one 
alkaloids from the cell cultures Tongkat Ali (Eurycoma longifolia Jack). J. Plant Biotech. 6(2): 125-130.

Stafford, A. \& Warren, G. 1991. Plant Cell and Tissue Culture. Buckingham: Open University Press.

Tada, H., Yasuda, F., Otani, K., Doteuchi, M., Ishihara, Y. \& Shiro, M. 1991. New antiulcer quassinoids from Eurycoma longifolia. Europ. J. Medic. Chem. 26: 345-349.

Zhao, D. Xing, J., Li, M., Lu, D. \& Zhao Q. 2001. Optimization of growth and jaceodin production in callus and cell suspension cultures of Saussurea medusa. Plant Cell, Tissue Org. Cult. 67: 227-234. 